\title{
VALIDITAS PENAFSIRAN DALAM TAFSîR BI AL-MA'TSÛR
}

\author{
Hairul Hudaya \\ Fakultas Tarbiyah dan Keguruan \\ IAIN Antasari Banjarmasin \\ Hp. 081356250316, email: hud hud05@yahoo.com \\ Diterima tanggal 10 Mei 2014 / Disetujui tanggal 11 Juni 2014
}

\begin{abstract}
There are three methods of interpretation used by commentators to interpret the Qur'anic verses, by riwayah, known as tafsîr bi al-ma'tsûr, by logic known as tafsîr bi al-ra'yi and by al-isyâri. From three methods of interpretation, according to Ibn Taymiyyah, tafsir bi al-ma'tsûr is the best method and valid. It is based on the belief that knows the meaning of the verse is Allah, the Prophet, and his companions. In fact, the commentary by al-ma'tsur, not the whole verse is interpreted by the Prophet, or friends but the majority carried out by commentators with ijtihadnya in placing the Qur'an, Hadith and friends opinion when interpreting a verse. Thus, differences in interpretation among commentators bi al-ma'tsûr can not be avoided. In case of Abrabam's son who was sacrificed, for example, between alThabari, Ibn Katsir and Ibn 'Athiyyah had different opinions and attitudes of understanding of the verses. While their interpretation is called tafsîr bi al-ma'tsûr. Their different opinions indicate that al-tafsîr bi al-ma'tsûr also need a review of the validity, especially related to commentator's thought in placing the explanation of Qur'an itself, Hadith and opinion in interpreting the Qur'anic verses.
\end{abstract}

Kata kunci: Validitas, Tafsîr bi al-Ma'tsûr, Tafsîr bi al-Ra'yi dan Tafsîr bi al-Isyari

\section{Pendahuluan}

Salah satu fungsi terpenting hadis terhadap Alquran adalah posisinya sebagai penjelas dari kandungan ayat atau sering disebut dengan bayan al-tafsîr. Dalam posisi ini, Nabi Saw. tidak bersifat pasif namun beliau turut aktif dalam menjelaskan kandungan ayat. Keaktifan ini dapat dipahami dari kandungan Q.S. al-Nahl/16: 44 yang menyatakan:

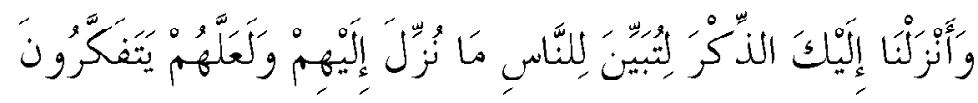

"Dan Kami turunkan kepadamu Alquran agar kamu menerangkan kepada umat manusia apa yang telah diturunkan kepada mereka dan agar mereka berpikir.”

Para mufassir memahami kata 'al-dzikr' dengan Alquran. Menurut al-Jazairi, ayat di atas bermakna bahwa kewajiban Rasul untuk menjelaskan Alquran menjadi sebab turunnya Alquran sehingga ia menyatakan bahwa Sunah tidak memerlukan Alquran karena fungsinya sebagai penjelas makna ayat yang masih mujmal (global). ${ }^{1}$ Makna yang hampir serupa terkait dengan fungsi Nabi sebagai penjelas Alquran juga terdapat dalam ayat 64 pada surah yang sama, di mana Allah berfirman:

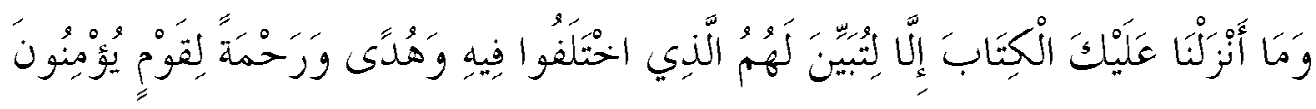

\footnotetext{
${ }^{1}$ Abu Bakar al-Jazairi, Aisar al-Tafasir (Maktabah al-Syamilah al-Ishdar al-Tsani), 272.
} 
"Dan Kami tidak menurunkan kepadamu Al-Kitab (Alquran) ini, melainkan agar kamu dapat menjelaskan kepada mereka apa yang mereka perselisibkan itu dan menjadi petunjuk dan rahmat bagi kaum yang beriman."

Pada ayat ini, Al-Jazairi kembali menegaskan arti penting peran Nabi sebagai penjelas kepada hamba-Nya atas wahyu yang telah Ia turunkan. ${ }^{2}$ Selain dua ayat tersebut, Nabi juga mempertegas posisi beliau sebagai penjelas Alquran yang bersifat aktif. Dalam sebuah hadis beliau menyatakan:

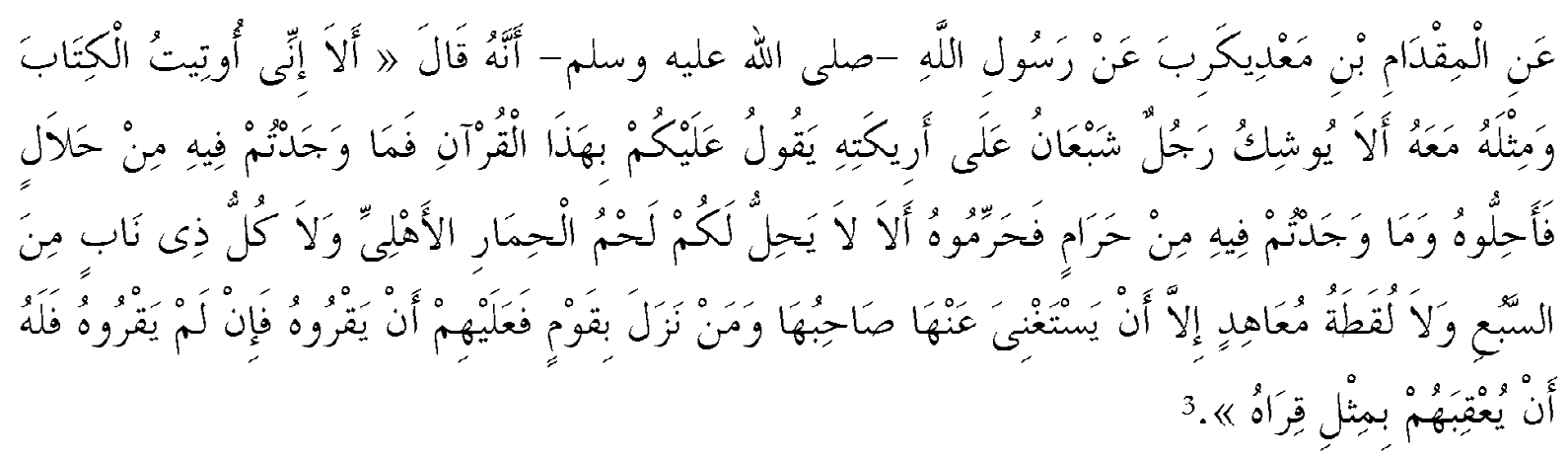

Dari al-Miqdan ibn Ma'dikarib dari Rasulullah Saw. beliau bersabda: "Ketabuilah bahwa sesunggubnya aku diberikan al-Kitab dan yang semisalnya (hadis). Ketahuilah, kelak akan ada orang bodoh yang bersandar di tempat duduknya sambil berkata: "Hendaklah kalian hanya berpegang pada Alquran dan apa yang dihalalkannya halalkan lah dan apa yang diharamkannya haramkan lah." Nabi Saw. kemudian menyatakan: "Ketahuilah, tidak dihalalkan bagi kalian daging kedelai jinak, hewan buas yang bertaring, harta mereka yang terikat perjanjian dengan kaum muslim kecuali jika mereka tidak memerlukannya. Jika ada orang yang bertamu hendaklah ia menjamunya dan kalau pun tidak hendaklah ia menggantinya sejumlah bentuk jamuan".

Hadis tersebut dikomentari al-Khaththabi dengan menyatakan bahwa hadis tidak perlu dihadapkan kepada Alquran dan suatu hukum yang ditetapkan oleh Rasulullah maka ia menjadi dalil dengan sendirinya. Sedang riwayat yang menyatakan bahwa jika disampaikan kepada kalian suatu hadis maka hadapkanlah ia dengan Alquran dan jika bersesuaian maka ambillah, riwayat ini menurutnya adalah batil. ${ }^{4}$

Keaktifan Nabi dalam menjelaskan Alquran menjadikan Ibn Taimiyah berlebihan dalam menilai fungsi Nabi tersebut. Menurutnya, Nabi menjelaskan seluruh makna Alquran kepada para sahabat sebagaimana beliau menjelaskan lafalnya. ${ }^{5}$ Namun pernyataan ini bertentangan dengan fakta bahwa tidak seluruh ayat dapat ditemukan hadis yang menjelaskan makna kandungannya, sehingga sebagian ulama menyatakan bahwa Nabi Saw. memang tidak menjelaskan seluruh makna Alquran namun hanya sebagian besarnya. ${ }^{6}$

Dalam hal ini, ada empat tingkatan dalam memahami Alquran, yakni pertama, ayat yang diketahui maknanya oleh semua orang sekalipun ia bodoh. Kedua, ayat yang dipahami orang Arab karena bahasa

${ }^{2}$ Al-Jazairi, Aisar al-Tafasir, 272.

${ }^{3}$ Abu Dawud Sulaiman al-Asy'ats al-Sijistani, Sunan Abu Dawnd (Riyadh: Bait al-Afkar al-Duwaliyyah, t.th.), 503.

${ }^{4}$ Syaraf al-Haq al-'Azhim Abadi, 'Aun al-Ma’bud 'ala Syarb Sunan Abu Dawud (Beirut: Dar Ibn Hazm, 2005/1426), 2134.

${ }^{5}$ Ahmad ibn 'Abd al-Halim al-Taimiyyah, Muqaddimah fi Ushul al-Tafsir (Kuwait: Dar al-Qur'an al-Karim, 1971), 35. Lihat juga Ahmad ibn 'Abd al-Halim al-Taimiyyah, Majmu'ah al-Fatawa Muqaddimah al-Tafsir, juz 13 (Cet. III; Kairo: Dar al-Wafa, 2005 $\mathrm{M} / 1426 \mathrm{H}), 177$.

${ }^{6}$ Muhammad H\#usain al-Dzahabi, al-Ittijahat al-Munharifah fi Tafsir al-Qur'an al-Karim Dawafi'uha wa Daf'uha (Cet. II; Kairo: Dar al-I'tisham, 1978), 11. 
mereka. Ketiga, ayat yang hanya dipahami oleh para ulama. Keempat, ayat yang maknanya hanya diketahui oleh Allah. Dalam konteks penafsiran Nabi Saw. atas ayat Alquran, maka bentuk penafsiran ketiga dan sebagian kecil kategori keempat inilah yang banyak dilakukan Nabi Saw. ${ }^{7}$

Dengan demikian, Nabi Saw. hanya menafsirkan sebagian ayat yang memang tidak dapat dipahami para sahabat, selebihnya merupakan medan ijtihad bagi para ulama untuk menafsirkannya. Dalam konteks corak penafsiran maka ayat yang ditafsîrkan Nabi Saw. termasuk dalam kategori tafsîr bi al-ma'tsûr, yang menurut Ibn Taimiyah, merupakan bentuk penafsiran terbaik. ${ }^{8}$ Lantas, apakah seluruh penafsiran ayat dengan menggunakan hadis yang terdapat dalam tafsîr bi al-ma'tsûr merupakan penafsiran Nabi Saw.? Apakah para mufassir bi al-ma'tsûr dalam menafsirkan ayat, semuanya menggunakan hadis yang sama? Apakah penafsiran yang terdapat dalam kitab tafsîr bi al-ma'tsûr, seperti tafsîr al-Thabari, tafsîr Ibn Katsir dan tafsîr Ibn 'Athiyyah, seluruhnya tepat dalam menampilkan hadis sebagai tafsîr atas suatu ayat? Artikel ini berusaha untuk mengkaji persoalan tersebut terkait validitas penafsiran ayat dengan ayat atau hadis dalam tafsîr bi al-ma'tsûr.

\section{Metode Tafsîr bi al-Ma'tsûr}

Dalam kajian tafsîr, setidaknya dikenal tiga model metode tafsîr yakni tafsîr bi al-ma'tsûr, tafsîr bi al-ra'yi dan tafsîr al-isyari. 'Tafsîr bi al-ma'tsûr, dengan ini, hanyalah sebuah metode dari beberapa metode yang digunakan ulama dalam memahami Alquran. Secara etimologi, kata ' $m a$ 'tsûr' berasal dari akar kata atsara-ya'tsuru-atsran yang berarti sisa sesuatu atau bekas jejak sesuatu. ${ }^{10}$ Namun, secara istilah, para ulama berbeda-beda dalam mendefinisikan tafsîr bi al-ma'tsûr. Berikut ini dikemukakan sebagian definisi tafsîr bi al-ma'tsûr dengan berbagai konsekwensi yang mengikuti definisi tersebut.

Definisi pertama, dan ini diperpegangi mayoritas ulama, menyatakan bahwa tafsîr bi al-ma'tsûr adalah:

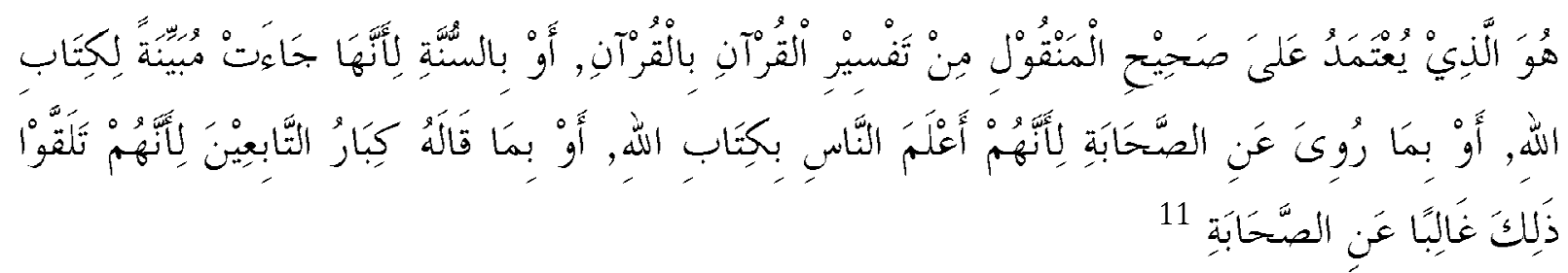

${ }^{7}$ Al-Dzahabi, al-Ittijahat al-Munharifah, 11-12. Al-Thabari juga berpandangan serupa yakni apa yang ditafsirkan Nabi saw. berkenaan dengan kategori ketiga ini sangatlah banyak jumlahnya sehingga tidak diperkenankan seseorang untuk menggunakan rasionya. Ayat yang ditafsirkan Nabi Saw. tersebut berkenaan dengan sesuatu yang wajib, sunah, petunjuk, larangan, hak dan budud (sanksi). Ayat mengenai hal tersebut tidak dapat dipahami tanpa merujuk pada penjelasan Nabi. Lihat, Didin Syafruddin, “The Principles of Ibn Taymiyya's Qur'anic Interpretation” (tesis tidak diterbitkan, Institut of Islamic Studies, McGill University, Montreal, 1998), 106. Penjelasan komprehensif mengenai kategori tafsir dapat dilihat, Muhammad 'Abd al-'Azhim al-Zarqani, Manabil al-'Irfan fi 'Ulum al-Qur'an, juz 2 (Beirut: Dar al-Kitab 'Arabi, 1995 M/1415 H), 11.

${ }^{8}$ Ketika ditanya tentang metode tafsir mana yang paling baik, Ibn Taimiyyah menjawab bahwa metode itu adalah Alquran menafsirkan ayat Alquran lainnya. Karena bila di suatu tempat terdapat ayat yang mujmal maka hal itu akan dijelaskan di tempat lain. Namun, apabila tidak ditemukan dalam Alquran maka hendaklah menafsirkan dengan sunnah karena ia berfungsi sebagai penjelas Alquran. Namun jika di kedua sumber tersebut tidak juga ditemukan penjelasannya maka hendaklah merujuk pada perkataan sahabat dan selanjutnya kepada penafsiran tabi'in. Lihat: Ibn al-Taimiyyah, Muqaddimah, 84-96.

${ }^{9} \mathrm{Al}$-Zarqani, Manabil al-Trfan, juz 2, 12. Dengan mempertimbangkan perkembangan ilmu tafsir, Manshur membagi metode tafsir menjadi tiga yakni tafsir bi al-ma'tsur, tafsir bi al-ra'yi dan tafsir maudhu'i. Sementara tafsir al-isyari dan al-ilmi bukanlah metode tafsir yang mainstream tapi lebih pada corak penafsiran dengan pemahaman tertentu. Lihat 'Abd al-Qadir Manshur, Mausu'ah 'Ulum al-Qur'an (Beirut: Dar al-Qalam al-'Arabi, 2002 M/1422 H), 186.

${ }^{10} \mathrm{Ibn}$ Manzhur, Lisan al-'Arab, juz 4 (Kairo: Dar al-Ma'arif, t.th.), 5. 
Tafsîr bi al-ma'tsûr adalah tafsîr yang didasarkan pada riwayat yang sahih baik dengan penafsiran Alquran dengan Alquran, hadis Nabi yang berfungsi sebagai penjelas Alquran, riwayat sahabat karena mereka orang yang paling banyak mengetahui tentang Alquran atau pendapat tabi'in senior karena mayoritas mereka menerima penafsiran Alquran dari sahabat.

Definisi di atas lebih lengkap bila dibandingkan dengan definisi lainnya. Dengan pengertian ini, sumber utama yang digunakan dalam tafsîr bi al-ma'tsûr adalah Alquran, Sunnah, qaul sahabat dan tabi'in..$^{12}$ Sumber kedua adalah fiqih dan ushulnya, bahasa Arab dan balaghahnya. ${ }^{13}$ Dengan demikian, meski tafsîr bi al-ma'tsûr mengandalkan riwayat dalam penafsiran namun dalam hal-hal tertentu tidak terlepas dari penafsiran nalar atau ra'yi.

Definisi kedua, tafsîr bi al-ma'tsûr adalah penafsiran dengan Alquran, Sunnah dan sahabat yang bertujuan untuk menjelaskan Alquran. Al-Zarqani mengemukakan definisinya dengan ungkapan:

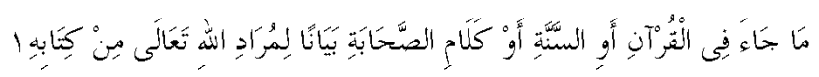

Menjelaskan maksud dari Alquran dengan ayat Alquran, sunnah atau perkataaan sahabat.

Dengan pengertian di atas, sumber tafsîr bi al-ma'tsûr menurutnya adalah Alquran, Sunnah dan sahabat. Sedang tafsîr tabi’in tidak termasuk dalam kategori tafsîr bi al-ma'tsûr. Menurut al-Zarqani, ulama berbeda pendapat mengenai tafsîr tabi'in. Ada yang menilainya sebagai tafsîr bi al-ma'tsûr dengan alasan karena mayoritas mereka menerimanya dari sahabat namun sebagian lain menilainya sebagai tafsîr bi al-ra'yi. ${ }^{15}$ Sedang al-Dzahabi beralasan karena dalam prakteknya yang disebut tafsîr bi alma'tsûr juga menggunakan riwayat tabi'in. ${ }^{16}$

Sejalan dengan pengertian tafsîr bi al-ma'tsûr tersebut, Ibn Tamiyyah memformulasikan langkahlangkah dalam menafsirkan Alquran, yakni:

1. Penafsiran Alquran dengan Alquran. Apa yang sifatnya umum, diperinci oleh ayat berikutnya dan ayat bersifat global akan ditemukan penjelasan pada ayat lainnya. Namun apabila tidak ditemukan maka dilakukan langkah penafsiran berikutnya, yakni:

2. Penafsiran Alquran dengan hadis. Salah satu fungsi Nabi Saw. adalah menjelaskan isi kandungan Alquran. Sehingga hadis berfungsi sebagai penjelas dan perinci ayat Alquran. Apabila tidak ditemukan maka melangkah pada penafsiran berikutnya, yakni;

3. Penafsiran sahabat. Para sahabat lebih memahami isi kandungan Alquran. Karena disamping Alquran diturunkan dengan gaya bahasa mereka, mereka juga memahami dan menyaksikan sebab turunnya Alquran, kondisi sosial, hal-hal yang menjadi sebab diturunkannya Alquran. ${ }^{17}$

Dalam hal ini, Ibn Taimiyyah juga tidak memasukkan tafsîr tabi’in sebagai salah satu sumber dalam memahami Alquran. Ia nampaknya sejalan dengan pandangan sebagian ulama yang memandang tafsîr tabi’in sebagai bukan bagian dari tafsîr bi al-ma'tsûr.

\footnotetext{
${ }^{11}$ Manna' al-Qaththan, Mabahits fi 'Ulum al-Qur'an (Cet. XI; Kairo: Maktabah Wahbah, 2000), 347. Bandingkan dengan definisi serupa yang dikemukakan oleh Muhammad Husain al-Dzahabi, al-Tafsir wa al-Mufassirun, juz 1 (Kairo: Maktabah Wahbah, 2000), 112.

${ }^{12}$ Shabri al-Mutawwalli, Manhaj Ibn Taimiyyah fi Tafsir al-Qur'an al-Karim (Kairo: 'Alam al-Kutub, 1981), 73.

${ }^{13}$ Al-Mutawwalli, Manhaj Ibn Taimiyyah fi Tafsir al-Qur'an al-Karim, 120.

${ }^{14} \mathrm{Al}$-Zarqani, Manabil al-'Irfan, 12.

${ }^{15} \mathrm{Al}$-Zarqani, Manabil al-'Irfan, 13. Lihat, Muhammad 'Ali al-Shabuni, al-Tibyan fi 'Ulum al-Qur'an (Beirut: 'Alam al-Kutub, 1985), 67, 70.

${ }^{16}$ Al-Dzahabi, al-Tafsir wa al-Mufassirun, 112.

${ }^{17}$ Fahd ibn 'Abd al-Rahman bin Sulaiman al-Rumi, Buhuts fi Ushul al-Tafsir wa Manahijih (Cet. IX; Riyadh: Maktabah alMuluk Fahd, 2009), 71.
} 
Definisi ketiga menyatakan:

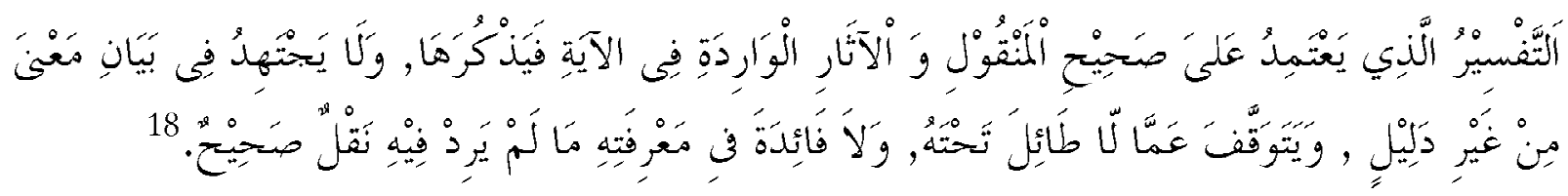

Tafsîr bi al-ma'tsûr adalah tafsîr yang [dalam menjelaskan maknanya] menyandarkan pada riwayat yang sahih dan hadis-hadis yang menjelaskan makna ayat.Penjelasan maknanya dengan menggunakan ijtihad tanpa didasarkan pada dalil dilarang.Tidak memberikan penjelasan yang tidak ada manfaat dan gunanya untuk mengetahuinya terlebih tidak adanya dalil sahih yang menjelaskannya.

Definisi di atas memberi pengertian bahwa tafsîr bi al-ma'tsûr haruslah disandarkan pada riwayat sahih yang memang menjelaskan ayat tersebut. Dalam tafsîr tersebut tidak diperkenankan adanya ijtihad mufassir tanpa disertai dalil yang berasal dari nash. Bersikap tawaqquf (menunda penafsiran) terhadap ayat yang tidak membawa manfaat untuk mengetahuinya terlebih tidak disertai dengan dalil dalam penjelasannya.

Ketiga definisi tafsîr bi al-ma'tsûr di atas, meski nampak sama namun bila dicermati lebih mendalam akan ditemukan sisi perbedaan yang sangat tajam. Definisi pertama yang dikemukakan oleh Manna' al-Qaththan menyatakan bahwa sumber tafsîr bi al-ma'tsîr sesungguhnya adalah riwayat yang berasal dari Nabi, sahabat atau tabi'in terkait penafsiran mereka terhadap ayat dengan syarat bahwa riwayat tersebut harus berkualitas sahih. Demikian juga definisi ketiga yang dikemukakan oleh Fahd. Berbeda dengan kedua definisi tersebut adalah yang dikemukakan oleh al-Zarqani. Meski samasama menyandarkan kepada Alquran, sunah dan perkataan sahabat dalam menafsirkan ayat namun tidak disyaratkannya jalur periwayatan dalam penafsiran menjadikan tafsîr bi al-ma'tsûr terbuka untuk masuknya pemikiran mufassir dalam menafsirkan ayat meski dengan menggunakan Alquran, hadis atau perkataan sahabat dan tabi'in.

\section{Validitas Penafsiran Ayat dengan Hadis}

Mengacu kepada definisi yang dikemukakan oleh Manna' al-Qaththan maka mufassir sesungguhnya dalam tafsîr bi al-ma'tsûr adalah Nabi Saw., sahabat dan tabi'in. Sementara itu, para mufassir yang namanya termuat dalam kitab tafsîr hanyalah berfungsi sebagai kompilator dari para mufassir tersebut. Sehingga, mufassir atau sumber tafsîr bi al-ma'tsûr dapat dirinci sebagai berikut:

1. Tafsîr Nabi Saw. dengan menggunakan Alquran

2. Tafsîr Nabi Saw. yang didasarkan pada pemahaman/sabda beliau (tafsîr Nabawi)

3. Tafsîr sahabat dengan menggunakan Alquran

4. Tafsîr sahabat dengan menggunakan hadis Nabi Saw.

5. Tafsîr sahabat dengan pendapat sahabat

6. Tafsir tabi'in dengan menggunakan Alquran

7. Tafsîr tabi'in dengan menggunakan hadis Nabi Saw.

8. Tafsîr tabi'in dengan pendapat sahabat

9. Tafsîr tabi'in dengan pendapatnya sendiri

Sampai pada tingkat tafsîr sahabat, semua bentuk penafsiran di atas yang merupakan bagian dari pembentuk tafsîr bi al-ma'tsûr tidak diperselisihkan validitasnya di kalangan ulama sejauh riwayatnya

\footnotetext{
${ }^{18} \mathrm{Al}$-Rumi, Bubuts fi Ushul al-Tafsir wa Manabijih, 71.
} 
berkualitas sahih. Alasannya adalah bahwa Nabi Saw. mendapat mandat dari Allah swt. untuk menjelaskan kandungan Alquran dan karenanya tidak mungkin keliru. Sedang sahabat adalah orang yang berinteraksi langsung dengan Nabi Saw., memahami konteks turunnya ayat dan sangat familiar dengan bahasa Alquran.

Terkait penafsiran sahabat dan tabi'in dalam tafsîr bi al-ma'tsûr, menurut Ahmad Amin, semula tafsîr bi al-ma'tsûr adalah tafsîr yang bersumber dari riwayat Nabi Saw. namun belakangan tafsîr tersebut berkembang dengan memasukkan riwayat yang berasal dari sahabat dan tabi'in. ${ }^{19}$ Bahkan, realitasnya berkembang sampai pada penafsiran mufassir yang masuk dalam tafsîr bi al-ma'tsûr yang ditulisnya meski tidak menghilangkan kekhasan tafsîr tersebut yakni menggunakan jalur periwayatan. Dalam hal ini, para mufassir tafsîr bi al-ma'tsûr menggunakan Alquran, hadis dan perkataan sahabat atau tabi'in untuk memahami suatu ayat berdasarkan hasil ijtihadnya yang sebenarnya bukan merupakan tafsîr Nabi Saw. atau sahabat secara langsung terhadap ayat tersebut.

Dalam kasus tafsîr bi al-ma'tsûr, para ulama seakan tidak membedakan antara penafsiran yang dilakukan oleh mufassir dengan menggunakan Alquran, hadis atau pendapat sahabat dengan penafsiran yang dilakukan oleh Nabi Saw. dan sahabat dengan menggunakan Alquran atau hadis. Padahal secara teologis, kedua bentuk penafsiran tersebut tentu berbeda validitasnya. Bila bentuk penafsiran yang berasal dari Nabi Saw. mutlak benarnya, sejauh hadis tersebut berkualitas sahih, namun berbeda halnya jika penafsiran tersebut berasal dari mufassir maka ia mengandung dua kemungkinan antara benar dan keliru karena merupakan hasil ijtihad mufassir meskipun menggunakan Alquran atau hadis dalam menafsirkan ayat.

Hal inilah yang disinyalir oleh Ahmad Amin sebagai satu penyebab dari kurang validnya tafsîr bi al-ma'tsûr. Ia menyatakan: ${ }^{20}$

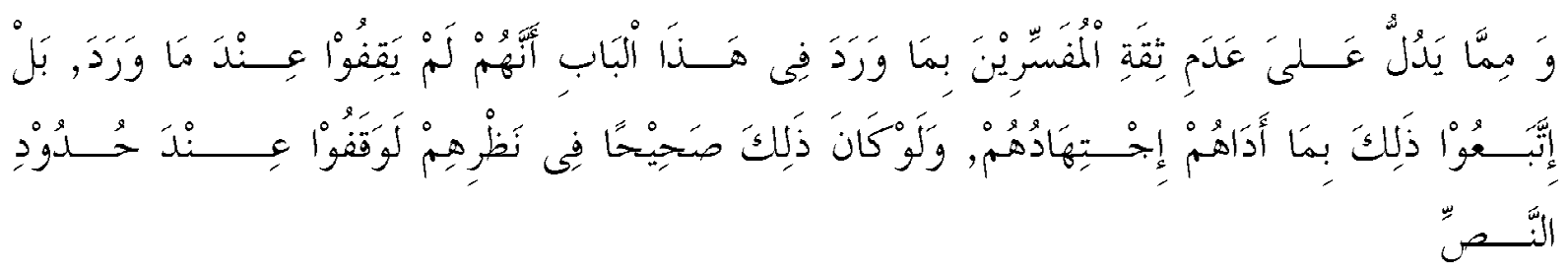

Dalam persoalan ini [tafsîr dengan hadis Nabi Saw.], yang menjadikan para mufassir kurang valid (tsiqah) adalah dikarenakan mereka tidak hanya menggunakan penafsiran yang berasal dari Nabi Saw. namun mereka juga menggunakan ijtihad [dalam menentukan hadis sebagai penafsiran ayat] meskipun penafsiran tersebut benar menurut mereka. [Meski demikian, bila ditemukan riwayat yang benar mengenai suatu tafsîr] mereka menafsirkannya berdasarkan nash tersebut.

Berkenaan dengan tafsîr Alquran dengan hadis, pernyataan Ahmad Amin tersebut di atas setidaknya mengisyaratkan beberapa hal. Pertama, bahwa dalam tafsîr bi al-ma'tsûr, penafsiran ayat dengan hadis tidak hanya didasarkan pada penafsiran Nabi Saw. terhadap ayat tertentu yang dapat ditemukan dalam kitab-kitab hadis terutama yang mengulas tentang kitab al-Tafsîr. Kedua, apabila tidak ditemukan penafsiran Nabi Saw. secara langsung terhadap suatu ayat, para mufassir menggunakan hadis untuk menafsirkan ayat berdasarkan ijtihad mereka. Ketiga, bahwa penafsiran tersebut tidak selamanya benar karena merupakan hasil ijtihad dalam proses memahami dua nash yang berbeda yakni Alquran dan hadis.

\footnotetext{
${ }^{19}$ Ahmad Amin, Fajr al-Islam (Cet. XI; t.t.: t.p., 1975), 199-200.

${ }^{20}$ Ahmad Amin, Fajr al-Islam, 199.
} 
Mengenai hal ini, para ulama tafsîr hanya menyatakan bahwa tafsîr bi al-ma'tsûrmerupakan penafsiran terbaik dibanding jenis tafsîr lainnya apabila memiliki rangkaian sanad yang sahih dan disandarkan pada Nabi Saw. atau sahabat. ${ }^{21}$ Apakah ini berarti bahwa riwayat yang dipersyaratkan kesahihan jalur sanadnya dalam tafsîr bi al-ma'tsûr adalah penafsiran yang berasal dari Nabi Saw. ataukah termasuk penafsiran yang dilakukan mufassir dengan menggunakan hadis Nabi Saw. berdasarkan ijtihadnya?

Ahmad Amin menyatakan bahwa penafsiran yang disandarkan pada para sahabat dan tabi in adalah hasil ijtihad mereka dalam menafsirkan ayat sehingga menghasilkan penafsiran yang berbeda antara satu dengan lainnya. ${ }^{22}$ Dengan demikian dapat dipahami bahwa kemudian dalam praktiknya banyak ditemukan perbedaan penafsiran antar mufassir bi al-ma'tsûr dalam menafsirkan satu ayat tertentu. Perbedaan tersebut salah satunya dipicu oleh perbedaan dalam menempatkan hadis yang digunakan sebagai sarana dalam menafsirkan ayat. Hal ini tentunya tidak terlepas dari asumsi 'ijtihad' dalam menempatkan hadis sebagai tafsîr ayat.

Pandangan Ahmad Amin yang menyatakan bahwa tafsîr bi al-ma'tsûr tidak hanya memuat penafsiran Nabi Saw. namun juga penafsiran mufassimya, juga dikemukakan oleh al-Thayyar. Menurutnya, tafsîr bi al-ma'tsûr mesti disematkan kepada penafsirnya. Jika mufassimya adalah Nabi Saw. maka dinamai dengan tafsîr Nabawi. Jika mufassimya adalah sahabat maka disebut tafsîr sahabat sedang bila mufassirnya adalah tabi'in maka dinamai tafsîr tabi’in. Penafsiran sahabat dan tabi'in yang menggunakan tafsîr Alquran dengan Alquran merupakan tafsîr bi al-ra'yi karena upaya penafsiran ayat tersebut dengan menggunakan akal dan ijtihad. ${ }^{23}$ Al-Thayyar kemudian membagi tafsîr al-Nabawi menjadi empat macam, yakni: ${ }^{24}$

1. Menjelaskan secara tekstual tafsîr atas suatu ayat atau lafal Alquran. Bentuk tafsîr ini mengambil dua model, yakni:

a. Menyebutkan tafsîr ayat kemudian diikuti dengan penyebutan ayat yang ditafsîrkan.

Contohnya adalah penafsiran Q.S. Maryam/19: 96, Allah berfirman:

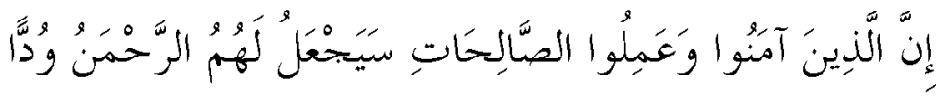

"Sungguh, orang-orang yang beriman dan mengerjakan kebajikan, kelak (Allah) Yang Maha Pengasih akan menanamkan rasa kasib sayang (dalam hati mereka)." 25

Ayat tersebut ditafsîrkan dengan hadis riwayat Abu Hurairah berikut:

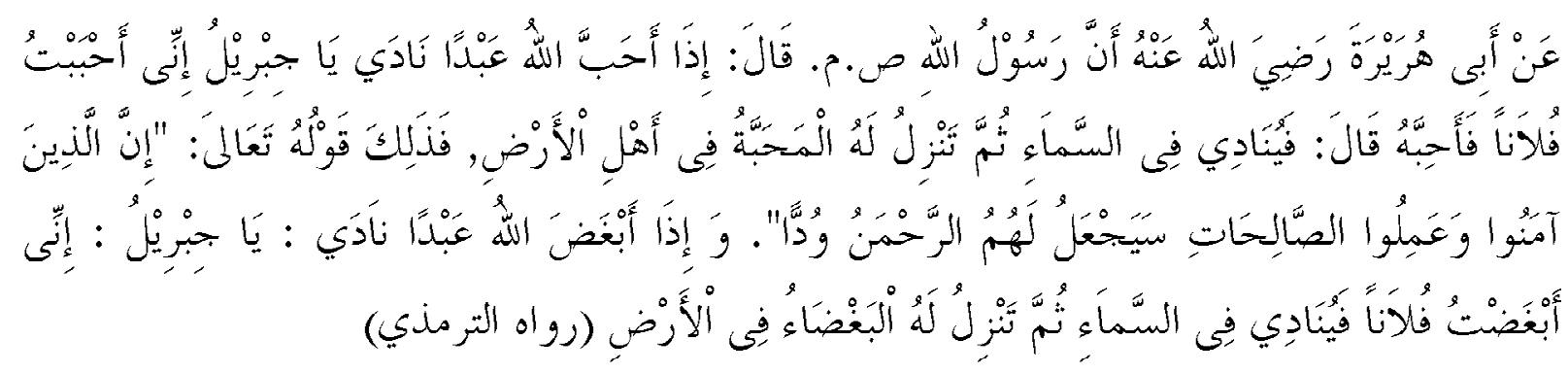

${ }^{21}$ Al-Shabuni, al-Tibyan fi 'Ulum al-Qur'an, 70.

${ }^{22}$ Ahmad Amin, Fajr al-Islam, 201.

${ }^{23}$ Musa'id ibn Sulaiman bin Nashir al-Thayyar, Fushulfi Ushul al-Tafsir (Cet. III; Saudi: Dar ibn Jauqi, 1999 M/ 1420 H), 54. Pernyataan tersebut nampak berseberangan dengan pendapat Ibn Taimiyyah yang menyatakan bahwa penfasiran yang bertentangan dengan apa yang ditafsirkan sahabat dan tabi'in adalah penafsiran yang keliru bahkan bid'ah karena merekalah yang lebih memahami makna dan mengetahui kebenaran. Lihat: al-Qaththan, Mababits fi 'Ulum al-Qur'an, 343.

${ }^{24} \mathrm{Al}$-Thayyar, Fushul fi Ushul al-Tafsir, 27-29.

${ }^{25}$ Departemen Agama RI, Al-Qur'an dan Terjemahnya, Edisi Tahun 2002 (Jakarta: CV. Darus Sunnah, 2007), 313. 
Dari Abu Hurairah r.a. bahwa Rasulullah Saw. bersabda: Apabila Allah mencintai seorang hamba maka ia akan menyeru: 'Wahai Jibril, sesungguhnya saya mencinta fulan maka cintailah ia. Nabi Saw. bersabda: Allah menyeru di langit maka penduduk bumi pun mencintainya. Inilah yang dimaksud dengan firman Allah: 'inna alladzina amanu wa 'amilu al-shalihat saja'alu lahum al-rahman wudda'. Namun apabila Allah murka kepada seorang hamba, Ia menyeru: 'Wahai Jibril, Saya murka pada fulan lalu Ia menyeru di langit lantas turunlah kemurkaan di muka bumi.

b. Menyebutkan ayat yang akan ditafsîrkan terlebih dahulu baru menyebutkan tafsîrnya. Sebagaimana penafsiran atas Q.S. al-Anfal/8: 60 yang berbunyi:

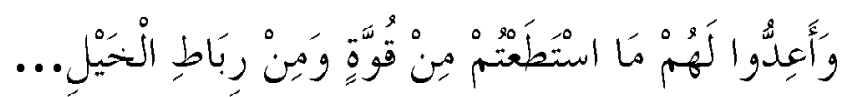

"Dan persiapkanlah dengan segala kemampuan untuk menghadapi mereka dengan kekuatan yang kamu miliki dan dari pasukan berkuda ..." ${ }^{26}$

Ayat tersebut ditafsîrkan Nabi Saw. melalui hadis Ibn 'Amir berikut:

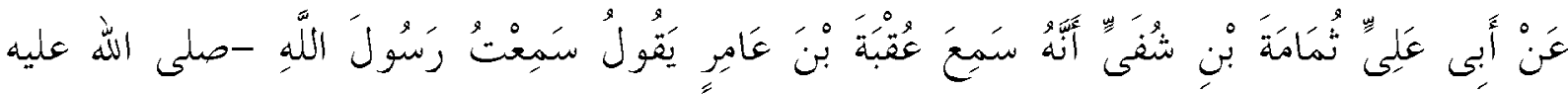

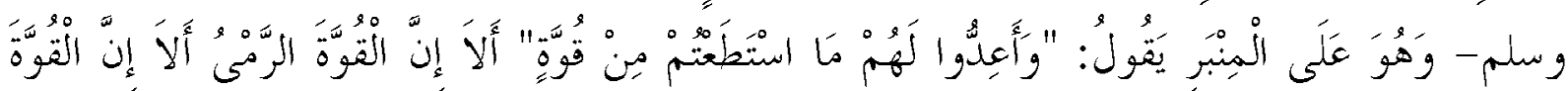

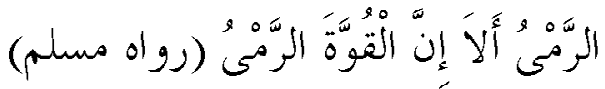

Dari Abu 'Ali Tsumamah ibn Syufay, ia mendengar 'Uqbah ibn 'Amir berkata, saya mendengar Rasulullah Saw. di atas mimbar berkata: Dan siapkanlah untuk menghadapi mereka kekuatan apa saja yang kamu sanggupi', yang dimaksud kekuatan adalah panah, kekuatan itu adalah panah, kekuatan itu adalah panah.

2. Sahabat mengalami kesulitan dalam memahami ayat lantas Nabi Saw. menafsirkannya. Hal tersebut sebagaimana diriwayatkan Abdullah ibn Mas'ud:

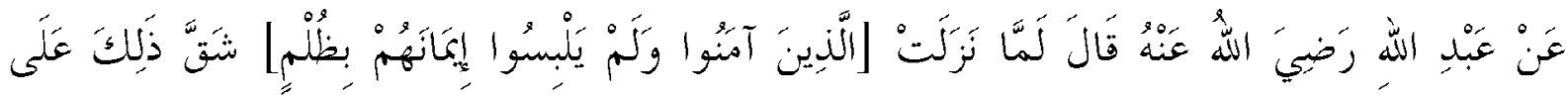

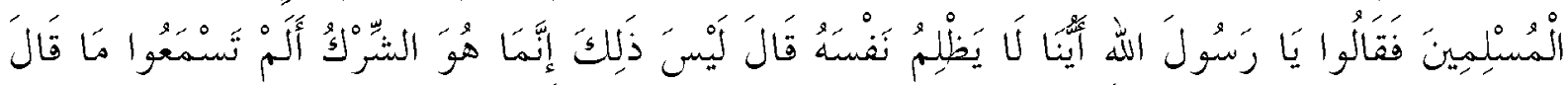

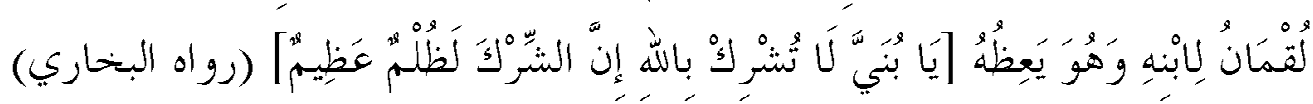

Dari 'Abdullah ibn Mas'ud r.a. berkata: ketika turun ayat 'alladzina amanu wa lam yalbisu imanabum bi zhulm' hal tersebut menyempitkan hari orang muslim dan mereka berkata: Wabai Rasulullah siapakah diantara kita yang tidak menzalimi dirinya? Nabi bersabda: 'Bukan itu yang dimaksud tapi adalah syirik, bukankah kalian mendengar nasihat Lukman kepada anaknya: 'Wahai anakeku janganlah kalian syirik kepada Allah karena sesungguhnya syirik tersebut kezaliman yang besar.

3. Nabi Saw. menafsirkan sendiri apa yang menjadi tafsîr atas suatu ayat. Sebagaimana ketika Nabi Saw. menafsirkan Q.S. al-Fajr/89: 23 yang berbunyi:

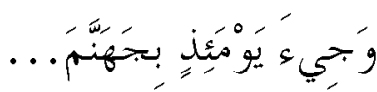

${ }^{26}$ Departemen Agama RI, Al-Qur'an dan Terjemahnya, 185. 
"Dan pada hari itu diperlihatkan neraka Jahanam ..."

Ayat tersebut ditafsîrkan Nabi Saw. melalui hadis yang diriwayatkan oleh 'Abdullah ibn Mas'ud menyatakan:

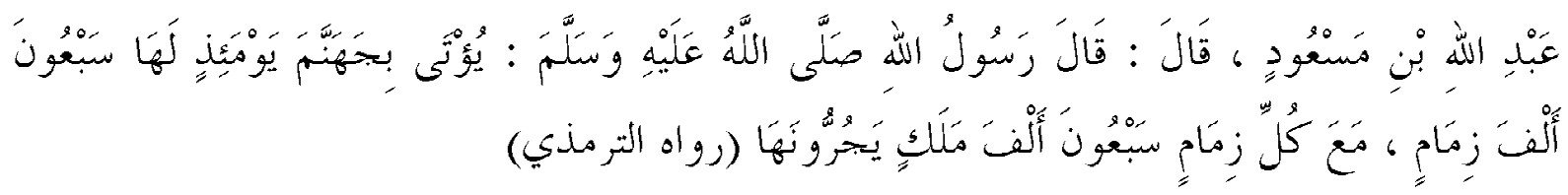

Dari 'Abdullah ibn Mas'ud berkata, bersabda Rasulullah Saw.: "Pada hari itu di neraka Jahannam didatangkan 70 ribu tali kekeang dan setiap talinya ada 70 ribu malaikat Malik yang menariknya."

4. Penafsiran dalam bentuk pengamalan yakni dengan melaksanakan apa yang diperintahkan dalam Alquran dan menjauhi apa yang dilarang. Sebagaimana firman Allah Q.S. al-Nashr/110: 3 yang berbunyi:

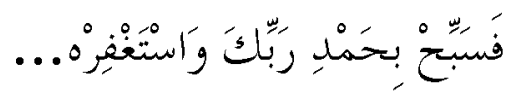

"Maka bertasbiblab dengan memuji Tuhanmu dan mohonlah ampunan kepada-Nya ..." 28

Ayat tersebut ditafsîrkan dengan pengamalan Nabi Saw. sebagaimana digambarkan 'Aisyah dalam hadis berikut:

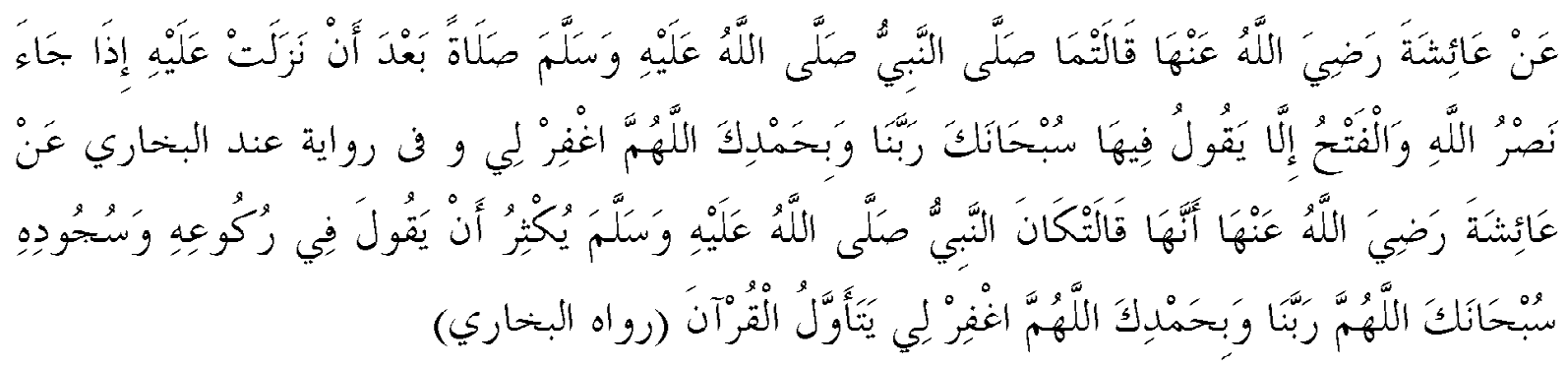

Dari 'Aisyah r.a berkata: 'Rasulullah tidak pernah shalat sesudah turunnya ayat 'idza ja'a nashr Allah wa al-fath' kecuali membaca 'subhanaka rabbana wa bihamdika Allahumma igfirli'. Dalam riwayat al-Bukhari lainnya dari 'Aisyah r.a. berkata: Nabi Saw. memperbanyak bacaan 'subhanaka Allabumma rabbana wa bihamdika Allahumma igfirli' sebagai pengamalan atas Alquran.

Penjelasan al-Thayyar di atas menunjukkan beragamnya jenis penafsiran Nabi Saw. atas ayat. Namun secara umum, penafsiran tersebut mengambil dua bentuk yakni, Pertama, penafsiran yang dilakukan atas inisiatif Nabi Saw. sendiri dan Kedua, penafsiran yang lahir atas pertanyaan sahabat.

Dalam perkembangannya, penafsiran Nabi Saw. yang diterima sahabat tersebut kemudian disampaikan kembali pada generasi berikutnya, tabi’in. Selanjutnya generasi tabi’in menyampaikannya kepada tabi' al-tabi'in. Namun, sebagaimana diuraikan sebelumnya, bahwa Nabi Saw. tidak menafsirkan seluruh ayat kepada para sahabat terutama ayat yang dapat mereka pahami berdasarkan bahasa dan konteks turunnya. Pada masa sahabat, ayat yang tidak ditafsîrkan Nabi Saw. kemudian ditafsîrkan sahabat dan demikian seterusnya, ayat yang tidak ditafsîrkan sahabat kemudian ditafsîrkan tabi'in berdasarkan ijtihad atas pemahaman mereka terhadap ayat. Penafsiran Nabi Saw., sahabat dan tabi’in

${ }^{27}$ Departemen Agama RI, Al-Qur'an dan Terjemabnya, 594. 
atas ayat Alquran dengan menggunakan jalur periwayatan inilah yang belakangan disebut dengan tafsîr bi al-ma'tsûr atau tafsîr bi al-riwayah.

\section{Contoh Penafsiran Ayat dengan Hadis Berdasar Ijtihad Mufassir bi al-Ma’tsûr}

Sebagaimana dikemukakan di atas bahwa tafsîr bi al-ma'tsûr tidak sepenuhnya merupakan tafsîr Nabi Saw. atau sahabat terhadap ayat namun juga memuat ijtihad mufassir dalam menafsirkan ayat dengan menggunakan Alquran atau riwayat berupa hadis dan pendapat sahabat. Berikut akan dikemukakan satu kasus ijtihad mufassir dalam menafsirkan ayat dengan menggunakan Alquran atau hadis. Di sini penulis akan membandingkan tiga tafsîr bi al-ma'tsûr berkenaan dengan ayat anak Nabi Ibrahim as. yang disembelih/dikurbankan. Ayat tersebut terdapat dalam Q.S. al-Shaffat/37: 107 yang berbunyi:

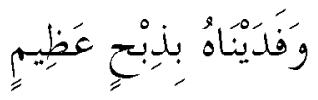

"Dan Kami tebus anak itu dengan seekor sembelihan yang besar."

Para mufassir tafsîr bi al-ma'tsûr berselisih pendapat mengenai siapa yang dikorban dalam peristiwa penyembelihan dan kemudian ditebus nyawanya digantikan dengan hewan sembelihan oleh Allah? Karena Nabi Ibrahim memiliki dua anak yakni Ismail dan Ishaq maka perbedaan mereka pun menyangkut dua nama tersebut. Dalam kesempatan ini akan dikemukakan pendapat dari al-Thabari, al- Ibn 'Athiyyah dan Ibn Katsir yang kitab tafsîr mereka dikategorikan oleh al-Zahabi sebagai tafsîr bi al-ma'tsûr sehingga layak diperbandingkan pendapatnya. ${ }^{29}$

Al-Thabari berpandangan bahwa anak Nabi Ibrahim Saw. yang dikorbankan tersebut adalah Ishaq. ${ }^{30}$ Pendapatnya ini didasarkan pada ayat, hadis serta riwayat dari para sahabat. Menurutnya, anak Nabi Ibrahim yang dikorbankan tersebut adalah anak yang dikabargembirakan kepadanya ketika ia meminta untuk diberi anak yang saleh. Sementara itu, dalam Alquran disebutkan bahwa anak yang Nabi Ibrahim mendapatkan kabar gembira (busyra) itu adalah Ishaq sebagaimana terdapat dalam Q.S. Hud/11:71 yang berbunyi:

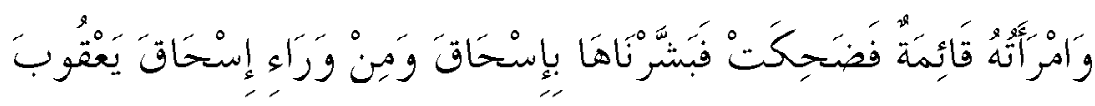

"Dan isterinya berdiri (dibalik tirai) lalu dia tersenyum, maka Kami sampaikan kepadanya berita gembira tentang (kelabiran) Ishak dan dari Ishak (akan lahir puteranya) Ya'qub."

Tambahnya lagi, setiap ayat Alquran yang berbicara tentang pemberian kabar gembira tentang akan lahirnya anak kepada Nabi Ibrahim selalu merujuk kepada Ishak. Menurut akal, Nabi Ibrahim tidak akan meminta untuk diberikan anak kecuali saat itu ia berada dalam keadaan tidak memiliki anak yang saleh dan tidak mungkin ia meminta jika hal itu telah Allah berikan. Jika Alquran menyatakan dalam setiap ayatnya bahwa Ishak adalah anak yang dikabargembirakan kepada Nabi Ibrahim maka tidak diragukan lagi bahwa ia adalah anak yang dikorbankan. ${ }^{31}$

${ }^{28}$ Departemen Agama RI, Al-Qur'an dan Terjemahnya, 604.

${ }^{29}$ Al-Dzahabi, al-Tafsir wa al-Mufassirun, 147.

${ }^{30}$ Muhammad ibn Jarir al-Thabari, Tafsir al-Thabari Jami' al-Bayan 'an Ta'wil Ayat al-Qur'an, ditahqiq oleh 'Abdullah ibn 'Abd al-Muhsin al-Turki, juz 19 (al-Qahirah: Markaz al-Buhuts wa al-Dirasat al-'Arabiyyah wa al-Islamiyyah, 2001/1422), 598.

${ }^{31}$ Al-Thabari, Tafsir al-Thabari, 598. 
Al-Thabari juga mengutip satu riwayat yang disandarkan kepada Nabi Saw. bahwa yang disembelih itu adalah Ishak. Riwayat tersebut berbunyi:

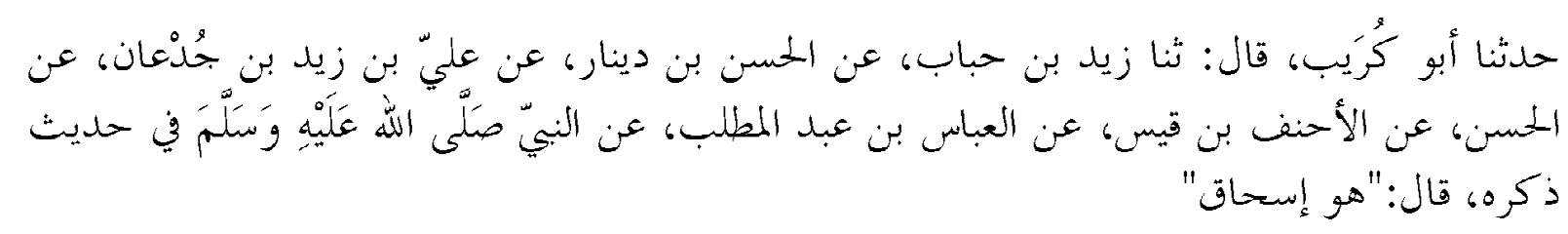

"Dari al-'Abbas ibn 'Abd al-Muthallib dari Nabi Saw. di satu hadisnya mengatakan: 'Ia adalab Ishak.."

Selain itu, ia juga mengutip pendapat para sahabat, diantaranya, Ibn 'Abbas, Ibn Mas'ud, Ka'ab al-Akhbar yang mengatakan bahwa Ishak adalah anak Nabi Ibrahim yang dikorbankan. ${ }^{32}$

Berbeda halnya dengan al-Thabari, Ibn Katsir dalam kitab tafsîrnya Tafsîr al-Qur'an al-Az̧bim, yang juga dinilai sebagai tafsîr dengan corak bi al-ma'tsûr, menyatakan bahwa anak Nabi Ibrahim yang disembelih itu adalah Isma'il anak pertama yang dikabar gembirakan kepada Nabi Ibrahim dan ia lebih tua dari Ishak. Sedang riwayat yang mengatakan anak tersebut adalah Ishak adalah dusta dan disandarkan kepada riwayat ahlul kitab. ${ }^{33}$ Pendapatnya ini disandarkan pada ayat yang menyatakan bahwa Nabi Ibrahim diberi kabar gembira akanlahirnya anak yang sabar atau halim dan ia inilah yang juga akan dikorbankan. Dalam Q.S. al-Shaffat/37: 101 dinyatakan:

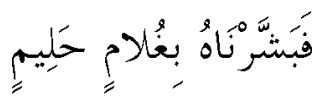

"Maka Kami beri dia kabar gembira dengan seorang anak yang amat sabar."

Dalam hal ini, Isma'il disifati dengan sifat halim. Sedang kabar gembira yang diterima Nabi Ibrahim berkenaan dengan Ishak disifati dengan kata 'alim (berpengetahuan) sebagaimana terdapat dalam Q.S. al-Hijr/15: 53 yang berbunyi:

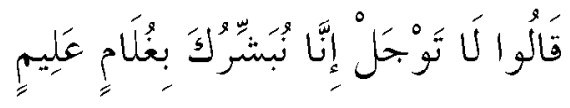

"Mereka berkata: "Janganlah kamu merasa takut, sesungguhnya kami memberi kabar gembira kepadamu dengan (kelabiran seorang) anak laki-laki (yang akan menjadi) orang yang alim."

Menurut Ibn Katsir, yang dimaksud dengan kalimat 'gulam 'alim' pada ayat di atas adalah Ishaq. Hal ini didasarkan pada Q.S. Hud/11: 71 yang berbunyi:

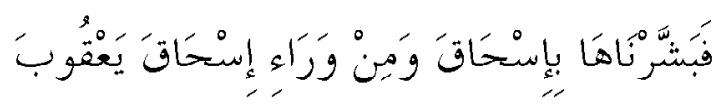

"Maka Kami sampaikan kepadanya berita gembira tentang (kelabiran) Ishak dan dari Ishak (akan labir puteranya) Ya'qub.”

Sementara itu, Ibn 'Athiyyah bersikap tawaqquf atau tidak menyatakan pendapat terkait perselisihan siapa nama anak Nabi Ibrahim yang dikorbankan tersebut namun ia mengemukakan kedua argumen yang disebutkan oleh kedua belah pihak. Ketika menafsirkan Q.S. al-Shaffat/37: 101 yang berbunyi:

${ }^{32}$ al-Thabari, Tafsir al-Thabari, 588-592.

${ }^{33}$ Isma'il ibn Katsir al-Dimasyqi, Tafsir al-Qur'an al-'Adzim, ditahqiq oleh Mushtafa al-Sayyid Muhammad dkk., juz 12 (Jizah: Muassasah Qurthubah, 2000/1421), 37. 


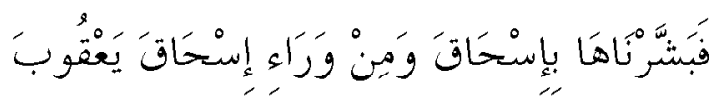

"Maka Kami beri dia kabar gembira dengan seorang anak yang amat sabar."

Ia mengatakan bahwa kebanyakan ulama, diantaranya al-'Abbas yang riwayatnya disandarkan kepada Nabi Saw., Ali, Ibn 'Abbas, Ibn Mas'ud, Ka'ab dan 'Ubaid ibn 'Amr menyatakan bahwa orang yang dijadikan kabar gembira tersebut adalah Ishak dan ia pula yang disembelih. Sedang ayat berikutnya yang juga menyampaikan kabar gembira dipahami sebagai kabar akan kenabian Ishak. Namun dalam tafsîrnya, ia juga menyatakan pendapat mereka yang mengatakan bahwa yang dimaksud dengan 'al-basyarab' atau kabar gembira tersebut adalah Ismail. Untuk kedua belah pihak yang berbeda pandangan tersebut, ia kemukakan beberapa riwayat yang menjadi dasar bagi masing-masing kelompok untuk membenarkan pendapatnya. Sementara itu, Ibn 'Athiyyah sendiri tidak menyatakan pendapatnya berkenaan dengan perbedaan pandangan tersebut. ${ }^{34}$

Ketiga kitab tafsîr tersebut menunjukkan dengan jelas adanya perbedaan pendapat dan penafsiran di kalangan para mufassir bi al-ma'tsûr yang dalam kasus di atas berkenaan dengan anak Nabi Ibrahim yang dikorbankan untuk disembelih. Al-Thabari menyatakan bahwa ia adalah Ishak sedang Ibn Katsir menyatakan sebaliknya yakni Isma'il sementara Ibn 'Athiyyah tidak memiliki sikap namun mengemukakan semua riwayat dan argumen dari kedua belah pihak yang berbeda terkait makna ayat tersebut. Meski ketiga tafsîr tersebut dikategorikan sebagai tafsîr bi al-ma'tsûrnamun hasil penafsirannya berbeda. Al-Thabari dan Ibn Katsir, misalnya, keduanya menggunakan tafsîr Alquran dan Alquran dalam menafsirkan ayat namun kesimpulan penafsirannya berbeda. Hal ini menunjukkan adanya peran ijtihad mufassir dalam menafsirkan ayat mesti itu adalah penafsiran Alquran dengan Alquran, Alquran dengan hadis atau Alquran dengan pendapat sahabat dan tabi'in.

Keadaan ini sangat memungkinkan disebabkan oleh berbagai hal. Pertama, penafsiran Nabi Saw. atas ayat sangat terbatas sehingga generasi yang hidup belakang menghendaki adanya pemahaman yang tidak ditemukan penjelasannya pada Nabi Saw. Kedua, diperbolehkannya seorang mufassir untuk berijtihad dalam menafsirkan ayat yang tidak ditemukan penjelasannya dari Nabi Saw. atau sahabat. Penafsiran tersebut dapat dilakukan baik menggunakan ayat maupun hadis yang dalam kaca mata mufassir dapat menjelaskan makna ayat. Kondisi ini membawa konsekuensi akan munculnya perbedaan antar mufassir dalam menafsirkan ayat meski menggunakan metode yang sama yakni tafsîr bi al-ma'tsûr. Karenanya, ada kemungkinan seorang mufassir dalam tafsîr bi al-ma'tsûr kurang tepat atau valid dalam menempatkan ayat atau hadis sebagai tafsîr atas ayat tertentu sebagaimana yang disinyalir oleh Ahmad Amin di atas.

\section{Penutup}

Berdasarkan uraian di atas dapat disimpulkan bahwa meski tafsîr bi al-ma’tsûr memiliki tingkat keakuratan yang tinggi untuk mendekati makna suatu ayat namun dalam faktanya tafsîr tersebut tidak dapat terlepas dari peran ijtihad mufassirnya. Munculnya perbedaan penafsiran dikalangan mufassir bi al-ma'tsûr mengenai tafsîr suatu ayat menjadi dasar kuat akan adanya ijtihad tersebut. Karena itu ada kemungkinan seorang mufassir bi al-ma'tsûr tidak valid dalam menafsirkan ayat dengan ayat tersebut atau ayat dengan hadis. Semua ini dikarenakan tidak seluruh ayat ditafsîrkan oleh Nabi Saw. dan para

\footnotetext{
34‘Abd al-Haq ibn Ghalib ibn 'Athiyyah al-Andalusi, al-Muharrar al-Wajiz fi Tafsir al-Kitab al-'Aziz, ditahqiq oleh 'Abd alSalam, juz 4 (Beirut: Dar al-Kutub al-'Ilmiyyah, 2001/1422), 480.
} 
mufassir diberikan lisensi yang cukup luas untuk memahami ayat berdasarkan ilmu dan kemampuannya. Penelitian ini sekaligus menjawab pernyataan Ibn Taimiyah yang menyatakan bahwa tafsîr bi al-ma'tsûr adalah tafsîr paling sahih atau valid tanpa membedakan antara tafsîr yang mufassirnya adalah Nabi Saw. sendiri dengan penafsiran para mufassir. Sejauh penafsiran tersebut berasal dari mufassir maka metode bi al-ma'tsûr sekalipun tidak dapat menjadi jaminan akan kevalidan dan kesahihan penafsirannya namun perlu kajian dan penelitian lebih jauh.

\section{DAFTAR PUSTAKA}

Abadi, Syaraf al-Haq al-'Azhim.' Aun al-Ma'bud 'ala Syarb Sunan Abu Dawud. Beirut: Dar Ibn Hazm. $2005 / 1426$.

Amin, Ahmad. Fajr al-Islam. Cet. XI. t.t.: t.p. 1975.

Al-Andalusi, 'Abd al-Haq ibn Ghalib ibn 'Athiyyah. al-Muharrar al-Wajiz fi Tafsîr al-Kitab al-Aziz, ditahqiq oleh 'Abd al-Salam. Beirut: Dar al-Kutub al-'Tlmiyyah. 2001/1422.

Departemen Agama RI, Al-Qur'an dan Terjemahnya, Edisi Tahun 2002. Jakarta: CV. Darus Sunnah. 2007.

Al-Dimasyqi, Isma'il ibn Katsir. Tafsîr al-Qur'an al-'Ad₹̨im, ditahqiq oleh Mushtafa al-Sayyid Muhammad dkk. Jizah: Muassasah Qurthubah. 2000/1421.

Al-Dzahabi, Muhammad H\#usain. al-Ittijahat al-Munharifah fi Tafsîr al-Qur'an al-Karim Dawafíuba wa Daf'uha. Cet. II. Kairo: Dar al-I'tisham: 1978.

Ibn Manzhur. Lisan al-'Arab. Kairo, Dar al-Ma'arif. t.th.

Al-Jazairi, Abu Bakar. Aisar al-Tafasir. Maktabah al-Syamilah al-Ishdar al-Tsani

Manshur, 'Abd al-Qadir. Mausu'ah 'Ulum al-Qur'an. Beirut: Dar al-Qalam al-'Arabi. 2002 M/1422 H.

Al-Qaththan, Manna'. Mababits fi 'Ulum al-Qur'an. Cet. XI. Kairo: Maktabah Wahbah. 2000.

Al-Shabuni, Muhammad 'Ali. al-Tibyan fi Ulum al-Qur'an. Beirut: 'Alam al-Kutub. 1985.

Al-Sijistani, Abu Dawud Sulaiman al-Asy'ats. Sunan Abu Dawud. Riyadh: Bait al-Afkar al-Duwaliyyah. t.th.

Syafruddin, Didin. “The Principles of Ibn Taymiyya's Qur'anic Interpretation”, tesis tidak diterbitkan, Institut of Islamic Studies. McGill University. Montreal. 1998.

Al-Rumi, Fahd ibn 'Abd al-Rahman bin Sulaiman. Bubuts fi Ushul al-Tafsîr wa Manahijih. Cet. IX. Riyadh: Maktabah al-Muluk Fahd. 2009.

Al-Taimiyyah, Ahmad ibn 'Abd al-Halim. Muqaddimah fi Ushul al-Tafsîr. Kuwait: Dâr al-Qur'an alKarim. 1971.

Majmu'ah al-Fatawa Muqaddimah al-Tafsîr. juz 13. Cet. III. Kairo: Dar al-Wafa. 2005 M/1426 $\mathrm{H}$. 
Al-Thabari, Muhammad ibn Jarir. Tafsîr al-Thabari Jami' al-Bayan 'an Ta'wil Ayi al-Qur'an, ditahqiq oleh 'Abdullah ibn 'Abd al-Muhsin al-Turki. al-Qahirah: Markaz al-Bubuts wa al-Dirasat al-'Arabiyyah wa al-Islamiyyah. 2001/1422.

Al-Thayyar, Musa'id ibn Sulaiman bin Nashir. Fushul fi Ushul al-Tafsîr. Cet. III. Saudi: Dar ibn Jauzi. 1999 M/1420 H.

Al-Zarqani, Muhammad 'Abd al-'Azhim. Manabil al-Irfan fi Ulum al-Qur'an. Beirut: Dar al-Kitab 'Arabi. $1995 \mathrm{M} / 1415 \mathrm{H}$. 